Relations industrielles

Industrial Relations

Roger WOLTERS, William H. HOLLEY : Labour Relations : An Experiential and Case Approach. New York, the Dryden Press, 1988, 321 pp., ISBN 0-03-069304-7

\title{
Mark Thompson
}

\section{Volume 44, numéro 4, 1989}

URI : https://id.erudit.org/iderudit/050546ar

DOI : https://doi.org/10.7202/050546ar

Aller au sommaire du numéro

\section{Éditeur(s)}

Département des relations industrielles de l'Université Laval

ISSN

0034-379X (imprimé)

1703-8138 (numérique)

Découvrir la revue

Citer ce compte rendu

Thompson, M. (1989). Compte rendu de [Roger WOLTERS, William H. HOLLEY : Labour Relations : An Experiential and Case Approach. New York, the Dryden Press, 1988, 321 pp., ISBN 0-03-069304-7]. Relations industrielles / Industrial Relations, 44(4), 957-958. https://doi.org/10.7202/050546ar

Tous droits réservés @ Département des relations industrielles de l'Université Laval, 1989
Ce document est protégé par la loi sur le droit d'auteur. L’utilisation des services d'Érudit (y compris la reproduction) est assujettie à sa politique d'utilisation que vous pouvez consulter en ligne.

https://apropos.erudit.org/fr/usagers/politique-dutilisation/ 
il demeure que la Charte aura un impact sur le droit du travail et les relations industrielles. Cet impact s'est d'ailleurs déjà manifesté, que ce soit seulement par le nombre d'instances où elle est invoquée. Ce seul phénomène est très important en lui-mềme, comme le note le professeur Arthurs.

Toute personne intéressée au droit du travail devrait prendre connaissance de cet ouvrage. Il révèle une dimension nouvelle et, pour plusieurs, inconnue de l'analyse dans ce domaine. C'est un ouvrage avant tout théorique qui tient autant des sciences politiques et de la philosophie que du droit. Il nous fournit un bel exemple d'une étude «on law» plutôt que «in law», selon l'expression de Bernard Adell'. Le lecteur du Québec constatera l'avancement de nos collègues du Canada anglais dans ce type d'étude par rapport à la recherche québécoise.

Par ailleurs, l'ouvrage présente les lacunes communes à tout collectif. On y note un manque d'uniformité dans l'analyse. Certains textes sont trop longs, d'autres un peu superficiels. Des répétitions inutiles se produisent d'un texte à l'autre, notamment dans l'analyse que certains auteurs font de la trilogie de la Cour suprême. On doit savoir gré à Bernard Adell qui a décelé un fil conducteur entre tous ces textes et proposé une introduction à leur lecture. Seul le texte de George Adams fait davantage bande à part, traitant des pouvoirs dont disposent les tribunaux face à une loi qui contrevient en tout ou en partie à la Charte. Bien qu'intéressante en soi, cette analyse ne s'inscrit pas dans la trame qui lie les autres textes ensemble.

De façon générale, l'ouvrage se lit bien. Les éditeurs ont fait un excellent travail. La présentation est fort acceptable et constante d'un texte à l'autre. Les auteurs ont su présenter leur position de façon claire et accessible à l'ensemble des lecteurs intéressés au domaine. Seul le texte de Brian Langille affiche des difficultés telles qu'il rebutera le lecteur non initié à la philosophie nord-américaine du droit.

Somme toute, malgré certaines lacunes, le livre publié par l'Université Queen's fait oeuvre utile. Il sensibilise le lecteur à une nouvelle dimension - combien fondamentale - de notre droit du travail. En fait, tout intéressé aux relations industrielles en général, et au droit du travail en particulier, devrait prendre connaissance du débat présenté dans ce livre. Cet exercice ne le laissera pas indifférent.

Gilles TRUDEAU

Université de Montréal

Labour Relations: An Experiential and Case Approach, by Roger Wolters and William H. Holley, New York, The Dryden Press, 1988, 321 pp., ISBN 0-03-069304-7

Despite the decline in industrial relations enrolments in the United States, new textbooks appear frequently, many with innovative features. This book is distinguishable from other labour relations textbooks by combining introductory discussions of principles typically found in texts with a large number of cases. Topics covered include the major labour relations problems confronted by the practitioner: the acquisition of bargaining rights by a union, negotia-

7 Bernard ADELL, «Le droit et les relations industrielles dans les juridictions canadiennes de Common Law», dans L'état de la discipline en relations industrielles au Canada, sous la direction de G. HÉBERT, H.C. JAIN et N.M. MELTZ, Monographie $\mathrm{n}^{\circ} 19$, Montréal, Ecole de relations industrielles, Université de Montréal, 1988, pp. 131 à 180. 
tion of collective agreements and the administration of labour contracts. In addition, there is a discussion of «labour relations in the nonunion sector». While the authors do not specifically limit their coverage to the private sector, there are almost no references to the public sector, and a number of concepts discussed, such as the scope of bargaining and bargaining power, are applicable only to the private sector.

The authors state that the book is to be used as a supplement to other texts (presumably for an introductory course), as a separate text for advanced undergraduate or graduate courses and seminars, or for use in courses aimed at «union and management practitioners». An instructor's manual is available.

For most readers of this journal, the most salient characteristic of the book is that it is written for an American audience. U.S. law and industrial relations practices pervade both the explanations of labour relations and many of the cases. In particular, the chapters on union organizing, contract negotiation and contract administration contain frequent references to the requirements of the Labor Management Relations Act or decisions of the National Labor Relations Board, many of them quite technical and at variance with Canadian law or practice. Thus, the book really would not be suitable for adoption outside of the United States.

Leaving aside the cultural and legal aspects of industrial relations in North America, the book has genuine merits as well as some problems. The explanations of the principles of industrial relations are well-written and generally appear to be accurate. In particular, the sections on the preparation for negotiations, the process of bargaining and preparing for an arbitration hearing are useful summaries of material seldom found in standard texts which do not rest on specifically American practices. Problems such as the selection of a negotiating team, the use of data in bargaining, interviewing witnesses and the like are clearly presented. Bargaining and arbitration simulations are realistic, offering ample scope for student involvement. Canadian readers who are interested in these subjects would find these sections of the book quite useful.

From a pedagogical perspective, however, a number of problems arise. Although one audience for the book is the advanced course, parts of the material is quite basic - descriptions of the number of steps in a typical grievance procedure, for instance, or the background on the Labor-Management Relations Act. Other areas seem excessively technical, especially the legal requirements for administering a union representation election. Most employers and unions facing these problems would obtain legal representation in lieu of mastering complex law and jurisprudence. Similarly, a great many of the cases in the chapters on union organizing and contract negotiations go to decisions of the National Labor Relations Board. The discussion of Board jurisprudence is necessarily brief, leaving students to struggle with issues for which precedent is available, but based on detailed information not available to them. Finally, the text contains no treatment of theory. Even concepts like distributive bargaining are mentioned, without being defined or discussed in detail.

A basic criterion for evaluating a book is its success in meeting its stated purpose or its relevance to the intended audience. In this case, the authors have been most successful in providing a casebook to supplement other texts, especially those which do not emphasize the practical side of labour relations. It is difficult to see this book in an advanced academic seminar, but it would probably be most effective for use with management practitioners. Its management orientation would make the book less appealing to union audiences.

Mark THOMPSON

University of British Columbia 